\title{
PENDIDIKAN MULTIKULTURAL DI PESANTREN (Upaya Membendung Radikalisme di Indonesia)
}

\author{
Siti Mahmudah Noorhayati \\ Institut Agama Islam Sahid Bogor \\ J. KH. Abduh Hamid KM. 6 Gunung Menyan, Pamijahan Bogor \\ E-mail: afieda_2006@yahoo.co.id
}

\begin{abstract}
Multicultural-Based Education in Pesantren (An Effort to Stem Radicalism in Indonesia). This study examines the role of pesantren in stemming radicalism. This is due to the wave of Islamic radicalism that keeps popping up on one side and terrorism on the other hand. It has disrupted the existence of pesantren. There is even a stigma that pesantren is a hotbed of terrorism and always fosters radicalism. Based on this fact, the conclusion of this study emphasizes the role of pesantren in stemming radicalism, that must be institutionally responsive and emphasize belief and morality. Pesantren education should be multicultural based, including an understanding of religious reality. As a religious education institution capable of processing and gathering all local wisdom in the face of Islam Nusantara, it is expected to deny the world's perception on Islam that is always identified with the religion of terror and hatred.
\end{abstract}

Keywords: multicultural education; pesantren; radicalism.

\begin{abstract}
Abstrak: Pendidikan Berbasis Multikultural di Pesantren (Upaya Membendung Radikalisme di Indonesia). Penelitian ini mengkaji tentang peran pesantren dalam membendung radikalisme. Hal ini disebabkan gelombang radikalisme Islam yang terus bermunculan di satu sisi dan terorisme di sisi yang lain telah mengganggu eksistensi pesantren. Bahkan bermunculan stigma bahwa pesantren adalah sarang terorisme dan selalu memupuk radikalisme. Berdasarkan kenyataan ini, maka simpulan dari kajian ini menekankan peran pesantren dalam membendung radikalisme, secara institusional harus responsif dan menekankan keimanan dan akhlak karimah. Pendidikan pesantren harus berbasis multikultural, termasuk di dalamnya pemahaman tentang realitas keberagamaan. Sebagai institusi pendidikan keagamaan yang mampu mengolah dan meramu segala kearifan lokal dalam wajah Islam Nusantara, pesantren diharapkan dapat membantah persepsi dunia tentang Islam yang selalu diidentikkan dengan agama teror dan kebencian.
\end{abstract}

Kata kunci: pendidikan multikultural; pesantren; radikalisme.

\section{Pendahuluan}

Pondok pesantren sebagai lembaga pendidikan dan lembaga sosial keagamaan merupakan lembaga tertua di Indonesia yang indegenous dengan beberapa identitas yang menjadi kekhasannya. ${ }^{1}$ Sebagai cerminan dari

1 Sebagai lembaga pendidikan tradisional di Indonesia, pesantren mampu bertahan sejak munculnya pendidikan kolonialisme Belanda hingga saat ini. Hal ini disebabkan bukan karena pesantren tidak hanya memerankan tradisionalnya, yaitu transmisi ilmu-ilmu Islam, pemelihara tradisi Islam, dan reproduksi ulama, juga sebagai agent of change (agen perubahan dan pembangunan masyarakat). Abdurrahman Wahid menyebutkan salah satu karakter dasar pesantren adalah kiprah besar pesantren dalam pengembangan ilmu keislaman tradisional dengan bingkai Aswaja yang disandingkan dengan kearifan lokal, bersifat pluralis dan berwatak kebangsaan. peradaban Islam Nusantara yang tidak lepas dari pembelajaran dan pengajaran, banyak hal yang dapat ditemui dan dirasakan dari pendidikan yang konon tidak mendunia ini.

Pada awal rintisannya, pesantren tidak hanya menekankan misi pendidikan, melainkan juga dakwah dan justru misi kedua ini lebih menonjol. Lembaga peninggalan para wali di Indonesia ini selalu mencari lokasi yang sekiranya dapat menyalurkan dakwah tersebut tepat sasaran sehingga terjadi benturan antara nilai-nilai yang dibawanya dengan nilai-nilai yang telah mengakar di masyarakat setempat. Lazimnya, baik pesantren

Abdurrahman Wahid, Pergulatan Negara, Agama dan Kebudayaan, (Jakarta: Desantara, 2001), h. 190. 
yang berdiri pada awal pertumbuhannya maupun pada abad ke-19 dan ke-20 berkelindan dengan kerawanan-kerawanan sosial dan keagamaan pada awal perjuangannya, ${ }^{2}$ yaitu berjuang melawan kepercayaan-kepercayaan selain Allah Swt dan juga takhayul. Pesantren tampil membawa misi keagamaan yaitu tauhid. ${ }^{3}$

Pesantren dalam perjalanannya mengalami banyak perubahan dan perkembangan secara alamiah bukan tanpa suatu rintangan. Sikap defensif ini dimaksudkan untuk menyelamatkan kehidupannya dan kelangsungan dakwah Islamiyah yang sudah melekat kuat. Pesantren tidak pernah memulai konfrontasi sebab orientasi utamanya adalah melancarkan dakwah dan menanamkan pendidikan. Dengan demikian, pesantren dengan mudah dapat diterima masyarakat sebagai upaya mencerdaskan, meningkatkan kedamaian dan membantu sosio-psikis bagi yang terjun di dalamnya. Tidak mengherankan jika pesantren menjadi kebanggaan masyarakat sekitarnya terutama bagi komunitas muslim. ${ }^{4}$

Ironi, jika dalam perkembangannya muncul stigma bahwa pesantren adalah the breeding ground, tempat perkecambahan radikalisme dan bahkan menjadi sarang pembiakan teroris, 5 utamanya pasca terjadinya beberapa kali pengeboman di Indonesia.

${ }^{2}$ Pada periode awal, pesantren memiliki peran besar tidak hanya pada perang fisik melawan penjajah tetapi juga berjuang melawan kepercayaan dan takhayul. Lihat, Mudjammil Qomar, Pesantren Dari Transformasi Metodologi Menuju Demokratisasi Institusi, (Jakarta: Penerbit Erlangga, 2005), h. 11.

3 Mastuhu, Dinamika Sistem Pendidikan Pesantren Suatu Kajian Tentang Unsur dan Nilai Sistem Pendidikan Pesantren, (Jakarta: INIS, 1994), h. 147.

4 Thomas Arnold dalam The Preaching of Islam mengatakan bahwa kedatangan Islam bukanlah sebagai penakluk seperti halnya bangsa portugis dan Spanyol. Islam datang ke Asia Tenggara dengan jalan damai, tidak dengan pedang, tidak dengan merebut kekuasaan politik. Islam masuk ke nusantara dengan cara yang benar-benar menunjukkan rahmatan lil 'alamin. Lihat, Pisdoni Mardianto, "Sejarah Masuk dan Berkembangnya Islam di Nusantara" dalam http://pisdonimardianto.blogspot. com/2015, diakses tanggal 28 Maret 2017.

${ }^{5}$ Meski sesungguhnya stigma ini sudah diklarifikasi oleh Prof. Irfan Idris dari BNPT yang bercerita bahwa sempat ada seorang peneliti terorisme yang mencurigai pesantren, ia kemudian menyamar sebagai pengajar bahasa Inggris dan tinggal di lingkungan pesantren. Selama tinggal di pesantren, peneliti mencari informai tentang kapan, dimana dan siapa saja yang melakukan pelatihan militer di pesantren. Namun hingga masa tinggalnya habis dan penyamarannya tidak pernah terbongkar, peneliti tidak pernah menemukan sama sekali bukti terorisme seperti yang didugakan sebelumnya. la bahkan bersimpati pada pesantren.
Melihat fenomena radikalisme yang terjadi selama ini, Islam sering dihubungkan dengan pesantren. Semakin menguatkan stigma ketika pelaku pengeboman di beberapa wilayah di Indonesia seperti bom Bali yang dalam pengakuannya merupakan alumni atau jebolan dari pesantren. Namun demikian, tidaklah bijak jika kemudian mengklaim bahwa jebolan pesantren terindikasi sebagai teroris. Pesantren yang sebagian besar figh oriented, berkarakter tawasuth (tidak memihak), tawazun (menjaga keseimbangan dan harmoni), tasammuh (toleransi) dan tasyawwur (musyawarah), berupaya menampilkan sikap akomodatif yang seimbang dengan budaya setempat tiba-tiba dikaitkan dengan persoalan ekstrim yang jauh dari tradisi dan praktek dunia pesantren.

Pada tahun 2016, Kepala Badan Nasional Penanggulangan Terorisme (BNPT) Saut Usman Nasution menyatakan telah menemukan 19 nama pesantren berpaham radikal yang berkaitan dengan figur teroris dengan level intensitas pengajaran yang variatif. ${ }^{6}$ Sesunguhnya temuan ini masih membutuhkan penelusuran secara detail, mengingat pihak BNPT dan Kemenag selaku representasi pemerintah di lingkungan pesantren belum menyamakan persepsi tentang ciri-ciri atau indikasi radikal. Namun demikian tidak menutup kemungkinan terdapat pesantren yang merupakan perpanjangan tangan dari gerakan radikalisme, sebagaimana yang diungkapkan oleh Sholahuddin Wahid7. Di luar itu, Wahid Institute dalam penelitiannya menemukan indikasi penyusupan embrio radikalisme dalam lingkup sekolah umum atau perguruan tinggi, yaitu melalui rohis. Pada tahun 2015 ditemukan buku Pendidikan Agama Islam kelas XI di sebuah SMA di Jombang berisi materi yang mengajarkan kekerasan, yaitu menyebutkan bahwa orang yang menyembah selain Allah adalah musyrik, dan musyrik boleh dibunuh. Di tahun berikutnya, muncul kabar ditemukannya buku ajar TK di Depok yang memuat unsur radikalisme, yaitu rela mati membela agama. ${ }^{8}$ Jauh sebelumnya, telah

6 “BNPT Incar 19 Pondok Pesantren Terindikasi Radikal" dalam http://nasional.komps.com, diakses tanggal 27 Maret 2016.

7 Sigit Pinardi, "Peneliti: Indikasi Pesantren Radikal Bisa Dilihat Pemimpin dan Alumninya” dalam http://m.antaranews. com/berita/544424, diakses tanggal 4 April 2017.

8 al-Mahfud, "Anak, Pendidikan Agama, dan Akar Radikalisme” dalam http://harian.analisadaily.com/, diakses tanggal 4 April 2017. 
ada penyebutan dan identifikasi bahwa terdapat beberapa pesantren yang secara ideologis serta berafiliasi financial ataupun kepemimpinan dengan kelompok Jamaah Islamiyah yaitu PP al- Mukmin Ngruki, PP Hidayatullah di Kalimantan Timur, dan PP al-Zaytun Indramayu, jenis pesantren yang dalam penyebutannya sebagai kelompok Islam radikal. ${ }^{9}$

Radikalisme dalam beragama dan bermasyarakat membawa instabilitas dan keresahan sosial, sebagaimana penyakit masyarakat lainnya yang mudah menular dan mempengaruhi pola pikir, seperti perjudian, narkoba, pencurian dsb, karenanya ia berpotensi untuk disingkirkan. Selain diklaim sebagai bentuk ancaman stabilitas dan penyimpangan dari arus utama tradisi agama yang mapan, radikalisme juga dianggap sebagai kritik terhadap agama mainstream yang tidak berpihak pada komunitas spirituality seekers, karena kenyataannya agama mainstream dalam kacamata mereka dituding gagal menyediakan ruang ekspresi bagi perkembangan spiritualitasnya. ${ }^{10}$

Banyak faktor pemicu radikalisme di pesantren diantaranya adalah faktor pendidikan, yaitu tercatat beberapa santri yang berstatus teroris adalah santri yang pernah mengenyam pendidikan di lembaga pendidikan yang berafiliasi dengan lembaga yang terindikasi teroris. Apakah itu dari sisi finansial atau sisi kepemimpinan kiai pesantren. Pendidikan pesantren yang memiliki afiliasi tersebut tentu akan memberikan kurikulum pendidikan yang berbeda dengan pesantren umumnya. Pendidikan yang demikian akan mempengaruhi pola berpikir santri, sebut saja karakter pemikiran alumni pesantren dari Malaysia, Afganistan dan kawasan Timur Tengah lainnya yang sudah mendapatkan pendidikan Islam radikal, seperti Ali Muchlas, Fathurrahman al-Gazi, Amrozi yang memeliki latar belakang sebagaimana tersebut di atas.

Pasca peledakan WTC dan Pentagon 11 September 2001 mengakibatkan meradangnya George Bush dan menyulut reaksi kegeramannya dengan mendeklarasikan war on terror, kalangan dunia Islam menjadi pihak yang dicurigai, termasuk

${ }^{9}$ Martin Van Bruinessen, "Netherlands Paper presented at the ISIM workshop on The Madrasa in Asia," dalam http:// murtaufuq.blogspot.com/2008_09_01_archive.html, diakses tanggal 26 Maret 2017.

${ }^{10}$ Roibin, Relasi Agama dan Budaya Masyarakat Kontemporer, (Malang: UIN Malang Press, 2009), h. 185. pesantren. Mereka seolah-olah ingin mengorek bahkan mengatakan bahwa dunia Islam itu tidak demokratis; tidak menerima perkembangan Barat yang liberal sehingga 'Islam' memilih jalan pintas yang tidak manusiawi. Islam dipahami sebagai agama yang anti globalisasi, anti peradaban, dan penebar api peperangan. Sementara pesantren yang sedari awal terkenal sebagai suatu lembaga pendidikan Islam dengan menjaga tradisi serta menekankan akhlak bagi santrinya, tiba-tiba harus menerima abu hangat, dicurigai dan dituding sebagai sarang teroris.

Akibat tuduhan yang tidak mendasar tersebut, penting kiranya untuk diklarifikasi oleh kiai dan seluruh stakeholders yang merupakan tiang utama dari pesantren, untuk meluruskan kepada khalayak bahwa pesantren adalah wahana pendidikan, dakwah dan pemberdayaan santri dan masyarakat yang menekankan pada aspek keimanan dan moralitas, bukan penyebar paham radikalisme agama yang sudah seharusnya tidak boleh berkembang di nusantara ini.

\section{Sekilas Tentang Fundamentalisme}

Secara historis, penggunaan istilah fundamentalisme berkaitan dengan kebangkitan fundamentalisme dalam gereja Protestan, khususnya di Amerika Serikat. Menurut Garaudy, fundamentalisme merupakan fenomena yang tidak terbatas pada agama namun juga dalam bidang politik, sosial dan budaya. Fundamentalisme yang demikian adalah suatu pandangan yang ditegakkan atas keyakinan, baik bersifat agama, politik ataupun budaya, yang dianut pendiri yang menanamkan ajaran-ajarannya di masa lalu dalam sejarah. Gagasan dasar fundamentalisme adalah suatu agama tertentu dipegang kokoh (harfiyah) dan bulat tanpa kompromi, pelunakan, reinterpretasi dan pengurangan."

Dalam bahasa Arab terdapat banyak konotasi fundamentalisme antara lain Islâmiyyun (kaum Islamis), ashliyyun (kaum otentik), salafiyyun (pengikut para sahabat pertama), muta'assib (militan yang suka kekerasan), ushûliyyun (kaum fundamentalis) dan ushûliyyah al-Islâmiyyah

${ }^{11}$ Yusril Ihza Mahendra, Modernisme dan Fundamentalisme dalam Politik Islam, terj. Mun'im A Sirry (Jakarta: Paramadina, 1999), h. 16-17. 
(fundamentalisme Islam). ${ }^{12}$ Ushûliyyun adalah mereka yang bertekad untuk kembali pada fundamen-fundamen pokok yaitu Alquran dan Hadis. Fundamentalisme juga berarti tajdid yang didasarkan pesan moral Alquran dan Sunah. ${ }^{13}$ Hal ini berbeda dengan fundamentalisme dalam kacamata Barat yang menyebutnya sebagai paham orang-orang kaku ekstrem serta tidak segan-segan berperilaku dengan kekerasan dalam mempertahankan ideologinya. Jika fundamentalisme dimaknai demikian maka sesungguhnya ini sangat berlawanan dengan ajaran-ajaran Islam.

Kekerasan agama sering disebut juga dengan radikalisme agama. Azyumardi Azra dalam berbagai kamus menyebut radikal sebagai kata sifat berarti "secara mencolok menyerukan atau meniggalkan cara biasa untuk kemudian mengikuti paham serta cara revolusioner dan ekstrem guna perubahan menyeluruh yang berdampak luas dan panjang". Sementara radikalisme adalah ideologi yang memercayai perubahan menyeluruh hanya bisa dilakukan dengan cara radikal, tidak dengan cara evolusioner dan damai. ${ }^{14}$ Orang-orang radikal adalah mereka yang menginginkan perubahan terhadap situasi yang ada dengan menjebol sampai ke akar-akarnya. Jadi, radikalisme dapat dipahami sebagai suatu sikap atau posisi yang mendambakan perubahan terhadap status quo dengan jalan menghancurkan status quo secara total, dan menggantinya dengan sesuatu yang baru, yang sama sekali berbeda. Biasanya cara yang digunakan lebih bersifat revolusioner, menjungkirbalikkan nilai-nilai yang ada secara drastis lewat kekerasan dan aksi-aksi yang ekstrem. ${ }^{15}$

Merujuk pada pengertian di atas tentu radikalisme berbeda dengan fundamentalisme. Fundamentalisme lebih merupakan sebuah keyakinan untuk kembali pada pondasi dan dasar agama. Namun fundamentalis ini akan menjadi radikal manakala memahami sesuatu dengan kekerasan dan anarkis, yang memunculkan paham

12 Azyumardi Azra, Pergolakan Politik Islam dari Fundamentalisme, Modernisme hingga Post-Modernisme, (Jakarta: Paramadina, 1996), h. 109.

${ }^{13}$ Muhammad Imarah, Fundamentalisme Dalam Perspektif Barat dan Islam, terj. Abdul Hayyie al-Kattani, (Jakarta: Gema Insani Press, 1999), h. 22.

${ }^{14}$ Azyumardi Azra, "Waspadai Paham Radikal”, Kompas, 7 April 2015.

${ }^{15}$ Amin Rais, Cakrawala Islam, (Bandung: Mizan, 1999), h. 132. terorisme, yaitu serangan yang terkoordinasi bertujuan untuk menimbulkan korban dengan melakukan hal-hal yang membahayakan seperti bom bunuh diri. Radikalisme dan terorisme merupakan dua entitas yang sama yaitu berusaha mengubah keadaan sesuai dengan tujuan yang dikehendaki secara instan sehingga bertindak secara ekstrem dan identik dengan kekerasan.

\section{Doktrin Radikalisme dan Terorisme}

Fenomena kelompok keagamaan di Indonesia, gerakan di luar tradisi agama mainstreamnya, tidak sedikit telah mencuri perhatian banyak kalangan. Kelompok ini dalam konteks keindonesiaan secara teologis dianggap sebagai agama sempalan atau sesat. Sempalan karena menyimpang dari akidah, ibadah, ritual maupun keyakinan otoritatif mayoritas masyarakat.

Padahal, pada hakikatnya kelompok tersebut merupakan sekelompok aktor yang sama-sama memiliki paradigma transendental dalam beragama, sebagai bentuk otoritas pemahaman keagamaan mereka terhadap doktrin agama tertentu. Gerakan yang merujuk pada suatu keyakinan keagamaan, etis, spiritual, dan filsafat. Istilah ini diambil oleh sarjana Barat sekitar tahun 70-an untuk menggantikan istilah lama cult (kultus) yang dalam perkembangannya kemudian berubah menjadi New Religious Movement. ${ }^{16}$

Gerakan-gerakan yang dilakukan pada prinsipnya merupakan ekspresi terdalam atas pemahaman terhadap agama yang diyakini. Terlepas apakah memang mereka memahami dan memaknai secara literal atau tidak, namun dapat kita saksikan bahwa perilaku atau sikap mereka menunjukkan bahwa pemahaman mereka terkesan parsial. ${ }^{17}$ Sayangnya, pemahaman parsial ini memaksa mereka untuk melakukan jihad dengan mengorbankan jiwa, raga dan harta. Tujuannya adalah demi memberangus orang-orang yang dalam perspektif mereka termasuk golongan kafir.

Kerangka pemikiran Islam radikal diletakkan berdasarkan asumsi bahwa Islam harus menjadi

${ }^{16}$ Roibin, Relasi Agama...., h. 186.

17 Sementara itu Rahman menyebutkan bahwa Islam dapat meembuahkan tata moral-sosial yang ideal apabila ditafsirkan secara benar dan bukan parsial., Fazlur Rahman, Islam dan Modernitas Tentang Transformasi Intelektual. Bandung: Pustaka, 2005), h. 153. 
dasar negara; syariat harus diterima sebagai konstitusi negara: bahwa kedaulatan politik ada di tangan Tuhan. Konsep Islam yang menyatakan tidak adanya perbedaan dalam kehidupan agama dan kehidupan dunia telah mendinamisasi sikapsikap masyarakat Islam dengan berusaha untuk membuat realitas yang mereka hadapi sesuai dengan nilai-nilai sebagaimana dikonsepsikan dalam Alquran. Dengan kata lain, konsep-konsep Alquran itu telah membentuk suatu yang menuntut semua muslim untuk membangun tatanan sosial politik mereka sesuai moralitas dan etika Alquran. ${ }^{18}$

Al-Islam; al-dîn wa al-daulah sebagai pandangan politik integralistik menghadirkan cara pandang dan perdebatan yang berimplikasi pada kelompokkelompok keagamaan. Bahkan sesama kelompok yang mengaku bersandar pada Alquran dan Hadis, dalam hal ini adalah pesantren yang notabene menyandarkan segala dinamika di dalamnya pure pada Alquran dan Hadis. Imbasnya, masyarakat menjadi buram dalam mengidentifikasi antara pesantren yang moderat dan pesantren yang terindikasi paham radikalisme.

Front Pembela Islam (FPI) adalah sebuah organisasi massa di Indonesia yang terbentuk pada tahun 1998, mengusung pandangan Islamisme konservatif untuk menegakkan hukum Islam di negara sekuler. Dalam deklarasi pendirian FPI yang dihadiri berbagai kalangan seperti para habib, tokoh masyarakat dan ulama menyatakan tentang penindasan umat Islam di Indonesia. Hal ini merujuk pada sejumlah peristiwa yang terjadi di Aceh, Lampung, Tanjung Priok, Haur Koneng dan Sampang yang notabene umat Islam menjadi korban, namun tidak diusut dan diselesaikan secara tuntas. Sebaliknya, mereka melihat peristiwa di Timor Timur yang dengan cepat diselesaikan. Sehingga memunculkan beberapa butir dalam deklarasi tersebut antara lain pembelaan terhadap umat Islam Indonesia yang menjadi sasaran penindasan. ${ }^{19}$

Sebagai salah satu ormas Islam yang berhaluan radikal di era reformasi yang bertujuan untuk membangkitkan rûhul jihâd (semangat jihad) dan menegakkan amar ma'ruf nahi munkar dalam

${ }^{18}$ Endah Turmudi dan Riza Sihbudi, Islam dan Radikalisme di Indonesia (Jakarta: LIPI Press, 2005), h. 111.

${ }^{19}$ Jajang, Gerakan ..., h. 131-132. ikatan ukhuwah islâmiyyah ${ }^{20}$ dengan gerakannya yang fokus pada pemberantasan tempat-tempat maksiat sebagai salah satu upaya penegakan syariat. Pemahaman kelompok ini menunjukkan sikap keberagamaannya yang eksklusif, cenderung totalistik, formalistik, simbolik dan literalis. Mereka memahami teks-teks agama bersifat kaku, dan menolak segala jenis penalaran akal dalam dunia keagamaan, sehingga cenderung merusak dan menghalangi Islam dari dinamisasi hidup yang vital dengan semangat jihadnya melakukan aktivitas tanpa kompromi. ${ }^{21}$ Gerakan ini menurut Azyumardi Azra adalah pemaknaan dan pemahaman mereka terhadap paradigma keagamaan atas konsep 'amar ma'ruf nahi munkar (menyeru kepada kebaikan dan mencegah pada kemungkaran). ${ }^{22}$ Dalam rangka mewujudkan misi tersebut salah satu langkah konkret yang dilakukan FPI adalah mensosialisasikan gerakan anti maksiat di tengah masyarakat secara nasional. ${ }^{23}$

Sejujurnya, kelompok radikal ini tidak menghendaki berdirinya negara Islam. Sebagaimana yang dikutip dari Habib Rizq bahwa Nabi Muhammad Saw tidak pernah memperbincangkan negara Islam, tetapi memperjuangkan bagaimana membentuk masyarakat Islam dan menegakkan syariat Islam didalamnya. ${ }^{24}$ Lebih lanjut menegakkan syariah dan menjaga akidah secara benar sangat diyakini oleh kelompok radikal dapat mengantarkan kejayaan peradaban Islam. Orientasi negara Islam yang disandarkan pada realitas historis pemerintahan Nabi di Madinah telah menjadi dambaan kelompok Islam radikal.

Sebaliknya, demokratisasi yang dianut pemerintahan selama ini dianggap sebagai pengadopsian sistem Barat yang menghambat terwujudnya penegakan syariat Islam. Demokratisasi tak ubahnya melahirkan sekulerisme, yang mengedepankan prinsip kebebasan dan hak asasi

\footnotetext{
${ }^{20}$ Sebagaimana dalam AD/ART FPI

${ }^{21}$ Kelompok Islam radikal ini sering menggunakan metode kekerasan dalam merealisasikan gerakan anti maksiat. Sejak berdirinya 1998, kelompok ini gencar melakukan aksi sweeping, seperti yang dilakukan di bulan Ramadhan di tahun 2001, yaitu penggerebekan pusat perjudian di Pluit, Jakarta Barat. Suara Hidayatullah, edisi 09.XII/Syawal 1422, h. 28.

${ }^{22}$ Azyumardi Azra, Pergolakan Politik Islam..., h. 109.

${ }^{23}$ Habib Rizieq Shihab, Dialog Piagam Jakarta: Kumpulan Jawaban (Jakarta: Pustaka Ibnu Sidah, 2000), h. 13.

${ }^{24}$ Khamami Zada, Islam Radikal: Pergulatan Ormas-ormas Islam Garis Keras di Indonesia,(Jakarta: Teraju, 2002), h. 17
} 
individu. Disinyalir, demokrasi memberikan ruang berkembangnya sikap toleran yang masif bagi tumbuhnya gagasan-gagasan baru, utamanya gagasan yang lahir dari Barat yang tidak sesuai dengan pokok ajaran Islam. Sebagai gantinya, kelompok ini menawarkan gagasan hakimiyyat Allah/ kekuasaan Tuhan, ${ }^{25}$ bahwa Islam berarti kepatuhan kepada kehendak Allah dan taat kepada hukumhukum-Nya.

Adapun jihad merupakan panggilan jiwa untuk membela Islam. Jihad yang secara lughowî berarti "bersungguh-sungguh dan berupaya keras" dimaknai sampai kepada qital fî sabîlillah. Jihad dalam perspektif kelompok radikal ini terpengaruh atas pemahaman literal terhadap ayat Alquran yaitu Q.S. al-'Ankabût [29]: 69, al-Furqân [25]: 52, dimana perjuangan individu atau masyarakat dipandang dengan perang suci. Dari pemahaman yang kaku inilah, bom terorisme menyeruak ke permukaan, menjadi hantu bagi seluruh jagat alam. Terorisme menjadi hantu kehidupan bagi umat manusia.

Bagi Gus Dur, ${ }^{26}$ fenomena radikalisasi agama disebabkan oleh kegagalan umat Islam untuk memahami sifat Islam yang sebenarnya dan hal ini yang memungkinkan berlanjutnya radikalisasi muslim di seluruh dunia. Untuk itu diperlukan cara untuk mengatasi ekstrimisme Islam dengan menjelaskan secara benar apa yang benar-benar Islam untuk muslim dan non-muslim. Agar tidak terjadi mispersepsi dan salah kaprah dalam memahami Islam sebagai agama penebar kedamaian.

\section{Pesantren dan Gerakan Islam Kontemporer}

Jatuhnya rezim Orde Baru telah membawa perubahan yang dahsyat bagi perkembangan gerakan-gerakan Islam. Radikalisme agama menyeruak ibarat bom waktu setelah lama dikungkung dan ditekan pada masa Orde Baru. Proses transisi yang dimulai ketika itu memberikan momentum yang tepat bagi gerakan Islam untuk bangkit dari keterpurukannya. Realitas ini menunjukkan bahwa kejatuhan rezim itu tidak saja diambil momentumnya oleh gerakan-gerakan Islam yang berhaluan radikal. Kemunculan Islam

${ }^{25}$ Bassam Tibi, Ancaman Fundamentalisme: Rajutan Islam Politik dan Kekacauan Dunia Baru (Yogyakarta: Tiara Wacana, 2000), h. 44.

${ }^{26}$ Abdurrahman Wahid, dalam the Wall Street Journal, $30 / 12 / 2005$. radikal yang pesat pasca Orde Baru telah melahirkan pertarungan yang cukup tajam, baik secara wacana ataupun gerakan.

Berkembangnya gerakan radikal telah memberikan warna yang berbeda pula dalam bagi perjalanan corak keberagamaan di Indonesia. Saat ini telah terjadi polarisasi yang sangat tajam antara Islam moderat dengan Islam radikal. Setelah Islam moderat berhasil mendapatkan tempat di hati penguasa sejak 1980-an, hingga kini di era reformasi mereka mendapat tantangan dari maraknya gerakan radikal yang muncul tak terbendung di seluruh lapisan masyarakat. Dengan berbagai slogan, opini dan gerakan yang terstruktur secara rapi mereka mampu mengambil dan menyedot perhatian publik sehingga gaung eksistensi mereka menjadi sesuatu yang tidak asing lagi di nusantara ini, khususnya dengan tuntutan Piagam Jakarta dan gencarnya tuntutan penerapan syariat Islam.

Inilah salah satu hasil dari gerakan era reformasi ${ }^{27}$ dengan agenda utamanya "demokratisasi", menyebabkan masyarakat Indonesia merasa dibuka dan diberi kebebasan untuk menyuarakan aspirasi pendapat dan politiknya, setelah sekian lama merasa dieksploitasi oleh pemerintah orde baru. Ditandai dengan keterbukaan, partai politik tumbuh subur, organisasi masyarakat berkembang pesat, begitu juga dengan organisasi keagamaan yang berorientasi fundamentalis, ${ }^{28}$ karena pada masamasa sebelumnya mereka tidak bisa bergerak akibat kekuasaan otoriter orde baru yang selalu mencoba untuk memarginalkan mereka.

Jika ditelusuri akar pemikirannya, gerakan Islam pasca reformasi terbagi menjadi beberapa

${ }^{27}$ Dalam konteks Orde Baru telah banyak “mengeksploitasi” Pancasila sebagai ideologi hegemonik negara. Pancasila tidak hanya diletakkan sebagai dasar negara, tetapi lebih jauh digunakan sebagai mekanisme kontrol sosial. Ideologi implikasi kebijakan ini akan menegasikan semua elemen civil society yang tidak patuh pada negara dicap sebagai makar, subversif, pemberontak, negara Islam dst. Pada era Orde Reformasi, Pancasila tidak lagi digunakan sebagai sarana atau alat hegemoni satu-satunya oleh pemerintah. Ada kecenderungan berbalik, yakni mulai memudarnya pemahaman tentang Pancasila. Fenomena yang tampak memberi kesan, bahwa negara tidak berdaya terhadap tekanan kekuatan masyarakat sipil yang mengusung ideologi atau kepentingan tertentu walaupun ideologi tersebut tidak sejalan dengan keinginan pemerintah. Rubaidi, "Negara Dan Radikalisme Agama di Indonesia" dalam Dialektika Teks Suci Agama, ed., Irwan Abdullah, dkk., (Yogyakarta: Pustaka Pelajar, 2008), h. 130.

${ }^{28}$ Fundamentalis termasuk dalam gerakan revivalis yang ide dasarnya adalah kembali pada ajaran Islam yang benar sebagaimana yang dipraktekkan oleh kaum salafusshaleh. 
ragam pemikiran dan gerakan. Merujuk pada visi ataupun misinya dapat dipetakan menjadi dua arus pemikiran utama yang sangat dominan yaitu literalisme dan liberalisme. ${ }^{29}$ Kelompok Islam literal biasanya mengusung ide-ide dan pemahaman keislaman yang 'eksklusif', cenderung menumpulkan pisau ijtihad dan merontokkan potensi akal hingga umat Islam terkesan terbelakang, membeo, tidak produktif, tidak memiliki spirit kreatif dan inovatif. Sedangkan kelompok liberalisme sebagaimana yang diproklamirkan untuk pertama kali oleh Charles Kurzman dalam bukunya Liberal Islam: a Source Book, kemudian diikuti oleh Leonard Binder yang berjudul Islamic Liberalism: a Critique of Development Ideologies, bersifat lebih terbuka, terhadap teokrasi, demokrasi, hak-hak perempuan, hak-hak non muslim, kebebasan berpikir, dan progresivitas. ${ }^{30}$

Di Indonesia dapat ditemukan kelompok representasi kategori Islam literalis ${ }^{31}$ yaitu Hizbut Tahrir Indonesia (HTI), Majelis Mujahidin Indonesia (MMI), Front Pembela Islam (FPI), Laskar Jihad (Ш), dan Kesatuan Aksi Mahasiswa Muslim Indonesia (KAMMI). Model pemikiran gerakannya adalah adanya legalisasi Islam dalam sistem sosial ataupun politik Indonesia. ${ }^{22}$ Sedangkan yang termasuk dalam Islam liberalis meliputi beberapa bidang dan menempuh berbagai cara. Gerakannya dalam bentuk LSM-LSM seperti Jaringan Islam Liberal (JIL), yang menjadi motor dan provokator liberalisasi pemikiran Islam, International Center for Religious Pluralism (ICRP), pembawa bendera pluralisme agama,

${ }^{29}$ Muhsin Jamil, Membongkar Mitos Menegakkan Nalar: Pergulatan Islam Liberal versus Islam Literal, (Yogayakarta: Pustaka Pelajar, 2005).

${ }^{30}$ Charles Kurzman, Wacana Islam Liberal: Pemikiran Islam Kontemporer tentang Isu-isu Global, (Jakarta: Paramadina, 2001), h. xiiv

${ }^{31}$ Organisasi yang termasuk dalam kelompok ini sering disebut sebagai "gerakan Islam Baru" dan asal muasal pemikirannya dari berbagai gerakan Islam di Timur Tengah. Yang mengimpor pemikiran dari Timur Tengah yaitu gerakan tarbiyah yang dekat dengan Ikhwanul Muslim, Hizbut Tahrir Indonesia merupakan cabang Hizbut Tahrir Internasional yang berpusat di Yordania dan kelompok Salafi yang memiliki jejaring dengan gerakan Salafi di Timur Tengah, khususnya Arab Saudi dan Kuwait. Lihat, Imdadun Rahmat, Arus Baru Islam Radikal, (Jakarta:Erlangga, 2005), h. 75.

${ }^{32}$ Ekspresi liberalisme Islam dalam bidang politik muncul agak belakangan. Indikasinya yang paling penting adalah lahirnya minat dan apresiasi terhadap paham egaliterianisme, demokrasi, dan wacana HAM yang mulai tampak ketika Islam bertemu dengan Barat. Karenanya, ekspresi pemikiran liberal dalam politik adalah menolak formula klasik. Mutawalli, JIL Menggugat Digugat, (Mataram: LKIM IAIN Mataram, 2009), h. 30.
Fahmina Institute, pengusung paham kesetaraan gender, Post Tradisionalisme (Post-Tra), Jaringan Intelektual Muda Muhammadiyah (JIMM), dsb.

Pandangan literalisme yang tidak memberika ruang yang layak bagi nalar dalam memahami Islam, dan melalui penawaran sebuah pemahaman yang vulgar atas makna literal Alquran dan Sunah. la menyajikan sebuah pola yang kaku dalam menghadapi setiap perubahan dan transformasi, sehingga nalar dan perubahan tidak punya pengaruh terhadap pemahaman atas Islam dan nilai-nilainya. Hasilnya, disuguhkan dua pilihan secara tegas antara Islam atau realitas perubahan dan transformasi di dunia. Sementara pandangan liberalisme beranggapan bahwa masyarakat harus sepenuhnya menyesuaikan diri dengan zaman, transformasi dan pencapaian intelektual manusia, dan atas dasar pencapaian itu harus mereview Islam, sekalipun hal itu mungkin meninggalkan banyak konsep-konsep religius dan elemen-elemen Islam yang termaktub dalam Alquran. ${ }^{33}$ Kedua pandangan kelompok tersebut telah memberikan 'warna' bagi kehidupan beragama dan bernegara di Indonesia. Pandangan kelompok pertama sebagai ikon dari kelompok yang kecewa terhadap ormas besar seperti NU dan Muhammadiyah yang tidak tegas dalam memperjuangkan aspirasi Islam. Sedang pandangan kelompok kedua menganggap NU dan Muhammadiyah sudah mulai kurang responsif terhadap isu-isu baru.

Kehadiran kelompok-kelompok keagamaan dengan ragam dan tipikalnya, fundamentalisme, konservatisme, modernisme-nasionalisme, sebagai gerakan wajah baru Islam di tanah air menjadi satu pertanyaan besar, apakah kehadirannya ini menjadi berkah atau ancaman bagi NKRI? Banyaknya aksi yang sering dilakukan kelompokkelompok keagamaan tertentu akhir-akhir ini tidak dapat dipungkiri cukup mencederai ${ }^{34}$ pesantren sebagai lembaga yang lekat dengan keagamaan.

33 Seyyed Mohsen Mirri, Muthahhari, Antara Literalisme dan Liberalisme, http://selak.blogspot.co.id/2010/02/muthahhariantara-literalisme-dan.html?m=1, diakses tanggal 26 Maret 2017.

34 Akibat maraknya gejala kekerasan atas nama agama, Islam banyak dituding oleh Barat sebagai sebagi biang keladi dari setiap ekstrimisme, anarkisme dan terorisme. Sementara Islam syarat dengan ajaran kasih sayang, humanisme, pluralisme dan demokratis. Q.S. Âli 'Imrân [31]: 31, Q.S. al-Fâtihah [1]: 1, Q.S. alHujurât [49]: 13, Q.S. al-An'âm [6]: 198, al- Hajj [22]: 4, al-Baqarah [2]:229, Q.S. Âli' Imrân: [3]: 159, Q.S. asy.Syurâ [26]: 38, dsb. 
Pesantren yang sedari awal memiliki aktivitas intrinsik dalam belajar mengajar, mulai dari gaya ortodoksi tradisional hingga pergulatannya dengan modernitas ${ }^{35}$ selalu berupaya untuk tidak meninggalkan nilai-nilai sufistik, ilmu hadis, fikih, tasawuf dan sebagainya. Sayangnya, nilai-nilai keunggulan tersebut akhir-akhir ini mengalami pergeseran dan memudar. Budaya keilmuan maupun budaya akvifitas kultural mulai terkikis. Seiring dengan menjamurnya pesantren model baru atau modernis yang cenderung tidak berbanding lurus dengan misi walisongo selaku penyebar Islam di Indonesia. Tetapi pesantren yang mengusung kemurnian Islam dengan gerakan transnasionalisme, gerakan yang cenderung struktural, identik dengan kekerasan dan pemaksaan bukan lagi berdasarkan kedamaian dan menyejukkan

\section{Pesantren dan Solusi Alternatif Membendung Radikalisme dan Terorisme Kontemporer}

Munculnya isu terorisme dan gerakan radikalisme kontemporer sebagaimana tersebut di atas berpotensi melumpuhkan nilai-nilai great tradition yang dimiliki dunia pesantren. Dalam menghadapi arus radikalisme agama langkah awal yang perlu segera dilakukan pesantren adalah setidaknya dengan dua sikap yaitu hati-hati dan kritis. Hati-hati yaitu pesantren harus berorientasi melahirkan santri yang tetap bersandar pada keteguhan iman, tafaqquh fi al-dîn menjadi satu hal yang mutlak dan sikap kritis yaitu mencetak santri yang berwawasan multikultural, berkemajuan, tangguh dan tanggungjawab menghadapi segala problematika.

Kamaruddin Amin dalam sebuah wawancara menuturkan bahwa pemerintah akan melakukan standarisasi pesantren melalui buku wajib dan standar kompetensi pondok pesantren. Standarisasi dimaksudkan untuk menguatkan ciri khas pesantren bukan menghilangkan ciri khas pesantren, salah satunya adalah penguatan dalam keilmuan hadis, tafsir dan sebagainya. Dalam hal ini pemerintah akan bersinergi dengan kalangan internal pesantren sehingga dapat meningkatkan kapasitasnya. Sinergi diarahkan supaya pesantren meningkat secara keilmuan dan

${ }^{35}$ Zamakhsari Dhofier, Tradisi Pesantren, (Jakarta: LP3ES, 1994), h. 41. keluaran pendidikannya mengarah pada keislaman yang moderat khas Indonesia. ${ }^{36}$

Merujuk pada statemen tersebut, secara tegas tulisan ini menawarkan tiga solusi alternatif pesantren dalam menangkal radikalisme agama; pertama, menekankan aspek keimanan yang merupakan bagian mendasar bagi dunia pesantren, kedua, memasukkan kurikulum multikulturalisme, dan ketiga mengawal jejak langkah islam nusantara. Dengan tiga alternatif ini, niscaya stigma buruk pesantren akan luntur dan terkikis dari kejahatan mass media yang berkontribusi aktif dalam memunculkan wajah pesantren saat ini.

Dengan menekankan aspek tafaqquh fi al-dîn pendidikan pesantren perlu menekankan pentingnya keimanan untuk meraih kemuliaan, kebahagiaan, ketenangan jiwa, menanamkan kecintaan kepada Allah dan penghuni alam semesta, untuk menanamkan akhlak. Iman adalah meyakini sesuatu yang benar-benar diimani sebagaimana dalam rukun iman. Jika pemahaman terhadap rukun iman dapat dipahami secara integral tentu akan melahirkan sikap dan perbuatan yang jauh lebih bermakna yaitu perbuatan baik terhadap sesama makhluk Tuhan. Konsep iman yang merasuk dalam kalbu santri akan menumbuhkan akhlak dan budi pekerti yang baik pula. Sehingga membentuk karakter santri yang santun dan berakhlakul karimah.

Menekankan pentingnya moral agama Islam sebagai pedoman hidup bermasyarakat dan 'persaudaraan' umat beragama. Meminjam bahasanya Amin Haedari 'pesantren harus membuka diri dengan masyarakat (inklusif), toleran dan hanif. Mengingat pemahaman corak ini tidak kaku dalam memahami Alquran dan Hadis. ${ }^{37}$ Memberi pemahaman terhadap santri bahwa 'bersaudara' tidak hanya menekankan pada aspek kesamaan iman. Melalui pendidikan inilah pesantren mampu menampilkan sisi humanismenya dan santun terhadap sesama umat beragama.

Pesantren harus selalu memupuk dan menumbuhkan semangat kreasi dan inovasi yang sudah menjadi kekhasannya pula dengan paradigmanya

${ }^{36}$ Yamin Mohammad, "Standarisasi Pesantren Membendung Radikalisme" dalam https://beritagar.id/artikel/berita/standarisasipesantren-membendung-radikalisme, diakses tanggal 7 April 2017.

37 Amin Hedari, et. al., Masa Depan Pesantren: Dalam Tantangan Modernitas dan Kompleksitas Global, (Jakarta: IRD Press, 2004), h. 234. 
the right tradition atau al-qadim al-shâlih (masa lalu yang baik) serta memelihara ilmu-ilmu yang memiliki keterikatan ide dengan intelektual Muslim masa lalu,,$^{38}$ dan mengambil sesuatu yang baru yang bagus pula. 39

Mengevaluasi dan berani mengadopsi sesuatu yang baru demi membuka cakarawala santri di pesantren menjadi keharusan. Kiai dan seluruh stakeholders dituntut bersikap bijak dan berpikir kritis dalam membuat formulasi sistem pengajaran dan kurikulum baru di pesantren, ${ }^{40}$ dengan menitikberatkan pada upaya rekonstruksi, pada konteks keindonesiaan, dengan mempertimbangkan kondisi masyarakat yang sedemikian plural, baik agama, etnis, maupun kepercayaan.

Pesantren selalu menyesuaikan dengan kultur budaya dimana ia berkembang. Dengan meminjam pernyataan Junaid al-Baghdadi bahwa Islam itu warna-warni, beraneka ragam, dan multikultural (la lawna lahu wa lawnuhu lawnaina'ihi). Terbukti pendidikan pesantren sangat dinamis sesuai dengan perkembangan zaman. Namun juga tetap bertahan dalam koridor syariat Islam dan tidak menyalahi kaidah yang menjadi identitasnya. Menerima

38 Abdurrahman Mas'ud, Dari Haramain ke Nusantara, (Jakarta: Kencana Prenada Media Group, 2006), h. 12.

39 Thoha Hamim dalam tulisannya "Pesantren Sebagai Alternatif Ideal Bagi Sikap Hidup di Tengah Modernitas" menyebutkan terdapat beberapa hal antagonisme pesantren terhadap modernitas, antara lain adalah metodologi pembelajaran, menjemen keorganisasian, teknologi, dan antipati pesantren terhadap budaya luar. Point keempat ditengarai sebagai embrio untuk menentang sekulerisme terhadap Barat yang kemudian memunculkan gerakan perlawanan. Lihat lebih detail, Thoha Hamim, "Pesantren Sebagai Alternatif Ideal Bagi Sikap Hidup di Tengah Modernitas" dalam Tadzkirah Jurnal Pendidikan Islam, Vol. 6 Th. 6, Februari 2011, (Jombang: UNIPDU, 2011), h. 22.

40 Terkait dengan metode pembelajaran dan kurikulum di pesantren terdapat beberapa pemikiran dan tulisan yang dapat dirujuk dan dikategorikan dalam skope ini antara lain pemikiran K.H. Abdullah Syafi'ie yang secara detail menjelaskan apa itu tujuan pendidikan pesantren, materi dan metode pendidikan, karakteristik guru dan murid, serta kelembagaan pendidikan pesantren di era modern. Lihat, Hasbi Indra, Pesantren dan Transformasi Sosial Studi Atas Pemikiran K.H. Abdullah Syafi'ie dalam Bidang Pendidikan Islam, (Jakarta: Penamadani, 2003), h. 166. Syed Muhammad Naquib al-Attas, (ed), Aims and Objectives of Islamic Education, (Jeddah: King Abdul Aziz University,1979), h. 1. Muhammad 'Athiyah al-Abrasyi, Dasar-dasar Pokok Pendidikan Islam, terj. Bustami A. Gani dan Djohar Bahry, (Jakarta: Bulan Bintang, 1993), h. 10. Syamsul Ma'arif, Pesantren vs Kapitalisme Sekolah, (Semarang: NEED'S Press, 2008), h. 106. Anin Nurhayati, Kurikulum Inovasi Telaah Terhadap Pengembangan Kurikulum Pendidikan Pesantren, (Tulungagung: Teras, 2010). Masnur Alam, Model Pesantren Modern Sebagai Alternatif Pendidikan Masa Kini dan Mendatang, (Jakarta: GP Press, 2011). dan terbuka dalam berbagai perbedaan, dalam konteks ini perlu kiranya mengajarkan paham multikulturalisme dan pluralisme di pesantren.

Paham multikultural menjadi penting untuk diperkenalkan di pesantren sebagai miniatur masyarakat multikultural, ${ }^{41}$ sebab dianggap mampu membawa kesadaran bagi para santri atau masyarakat pesantren agar dapat membuka visi pada cakrawala yang semakin luas, mampu melintas batas kelompok etnis, tradisi budaya dan agama mereka sehingga mereka mampu melihat kemanusiaan sebagai sebuah keluarga yang memiliki perbedaan ataupun kesamaan citacita. Inilah sebuah kurikulum pendidikan akan nilai-nilai dasar kemanusiaan untuk perdamaian, kemerdekaan dan solidaritas.

Pesantren menyuguhkan Islam secara hanif dan toleran karena masyarakat Indonesia dalam kenyataannya merupakan masyarakat yang majemuk dan masyarakat yang multikultur. Oleh sebab itu, dalam masyarakat yang multikultur, pendidikan Islam juga harus mengarah pada perkembangan multikultural, bukan masyarakat monokultur. Masyarakat multikultural merupakan masyarakat yang menghargai dan menjunjung tinggi harkat dan martabat manusia, sehingga jelas pengakuannya terhadap masing-masing individu.

Penanaman multikulturalisme di pesantren senantiasa mempertemukan nilai-nilai yang berbeda serta pandangan-pandangan yang berbeda pula. Pertemuan nilai-nilai dan pandangan yang berbeda ini diharapkan mampu menjadi bagian dinamisasi dari human being yang berkembang dari santri. Dalam konteks Indonesia yang majemuk, menjadi penting untuk direalisasikan sebab pesantren yang telah menanamkan paham multikulturalisme dapat dilihat sebagai bagian dari upaya komprehensif mencegah dan menanggulangi konflik etnis agama, radikalisme agama, separatisme, dan integrasi bangsa, sedangkan nilai dasar dari konsep multikulturalisme adalah toleransi. Hal ini berbeda dengan radikalisme yang lebih mengedepankan kekerasan dalam menyelesaikan masalah.

Konsep multikulturalisme di pesantren, menyadarkan seorang santri dan komunitas masyarakat

${ }^{41}$ Hamam Faizin, "Pesantren Wajah Multikultural Islam Indonesia" dalam Pesantren dan Demokrasi, Jejak Demokrasi Dalam Islam, (Jakarta: Titian Pena, 2010), h.238. 
untuk berpegang pada idealisme, mengembangkan kemampuan intelektual, dan perilaku yang mulia untuk menata serta membangun karakter bangsa yang makmur dan berperadaban. Pesantren pada umumnya berkarakter plural, tidak seragam dan tidak memiliki wajah tunggal. Penampakannya saja terkesan seragam tapi sesungguhnya beragam, dan sifat konservatif yang melekat padanya, nyatanya lambat laun bahkan secara terangterangan mampu mengubah diri, mengimbangi denyut perkembangan zaman.

Seiring dengan perubahan sosial dan juga derasnya paham radikalisme agama, pesantren dituntut untuk dapat memandang pluralitas keindonesiaan dalam berbagai aspek sosial, ekonomi, politik, budaya dan agama sebagai kekayaan spiritual bangsa yang harus tetap dijaga dan dilestarikan. Pesantren harus mampu dan berupaya mengendepankan santri untuk dapat mengekspresikan dan mengapresiasi dialog secara mandiri, menghimpun berbagai pemikiran dan pandangan dari berbagai kalangan yang memiliki kepedulian terhadap peran agama dalam memecahkan problem sosial yang ada.

Multikulturalisme merupakan titik temu berbagai budaya meniscayakan kesetaraan dan penghargaan di tengah pluralitas budaya. Dalam konteks ini pesantren dituntut proaktif, merespon dengan menampilkan santri yang secara kritis dan kreatif berdialog dengan budaya lokal ataupun luar, sekaligus memodifikasi menjadi budaya baru yang dapat diadopsi dan dikembangkan di pesantren dan lingkungannya. Sebagaimana yang pernah dilakukan oleh Sunan Kalijaga yang berhasil mendialogkan budaya lokal dan Islam, spirit Islam mengisi ruang budaya lokal yang berkembang.

Multikulturalisme pesantren juga mendukung pengembangan sifat toleransi sehingga di masyarakat pesantren tumbuh pemahaman yang inklusif untuk harmonisasi agama-agama di tengah kehidupan masyarakat plural yang melindungi keberadaan berbagai variasi agama. Di sini pesantren menjadi garda depan dalam memerangi fanatisme mazhab atau taklid buta.

Di era globalisasi, telah terjadi pertemuan dan gesekan nilai-nilai budaya dan agama di seluruh dunia yang memanfaatkan komunikasi, transformasi dan informasi hasil modernisasi teknologi. Di sinilah, pesantren harus membuka diri untuk memanfaatkan fasilitas teknologi, santri harus bisa memainkan perannya, mengasah kemampuan untuk mensejajarkan diri dengan masyarakat di luar darinya. Dengan aksioma khudz ma shafa wa da'ma kadar (ambil yang jernih dan buang yang kotor), niscaya pesantren memiliki wawasan dan bekal yang luas dalam memandang dunia (world view).

Di sinilah, urgensi kurikulum pendidikan multikulturalisme yang mampu menciptakan nuansa transformatif dan dialogis terhadap budaya lain. Membuka diri, mengapresiasi, menghormati, saling mengisi dan melengkapi bukan sebaliknya yaitu penetracion pacifigure atau menghadirkan kekerasan dan egosentris. Tradisi kebersamaan dan kebhinekaan patut dikedepankan sehingga kehidupan yang plural di tanah air dapat terwujud secara damai dan konstruktif.

Salah satu hal yang mengakar dan menjadi ikon pesantren adalah kemampuannya untuk mengolah dan meramu segala kearifan lokal untuk menjadi satu bagian penting dalam perkembangan dunia Islam. Pesantren memiliki potensi menjadi garda depan, mengawal Islam Nusantara dan pluralisme agama.

Konferensi internasional mengenai Islam moderat di Indonesia yang baru diselenggarakan di Kampus Vrije Universiteit Amsterdam dengan mengangkat tema "Rethingking Indonesia's Islam Nusantara: From Local Relevance to Global Significance" merupakan agenda besar yang tidak lain ingin menyampaikan dan menampilkan sisi kehidupan Islam Nusantara di Indonesia terhadap upaya-upaya global atas berbagai persoalan yang dihadapi umat manusia di seluruh dunia dewasa ini, seperti kekerasan ${ }^{42}$ sektarian, ketimpangan sosialekonomi, xenophobia, Islamphobia, dan sebagainya.

Untuk menguatkan pesan kunci ini, hasil-hasil konferensi kemudian dirumuskan dalam bentuk Piagam Den haag yang berjudul "Islam Nusantara untuk Perdamaian, Keadilan dan Persaudaraan Seluruh Umat Manusia" yang berisi dua konsideran pertama berturut turut mengangkat persoalan global yang dihadapi umat manusia dewasa ini dan bagaimana persoalan global tersebut telah

${ }^{42}$ Konferensi Internasional Islam Nusantara Hasilkan Piagam Den Haag, www.kemenag.co.id/berita/480851/konferensi, diakses tanggal 4 April 2017. 
melemahkan otoritas pemerintah yang sah dan sekaligus memberi peluang bagi sebagian kelompok untuk mengampanyekan populisme dan kekerasan atas nama etnis dan agama. Konsideran ketiga menggarisbawahi kontribusi besar yang diperankan Islam Nusantara sebagai faktor pengikat kemajemukan bangsa Indonesia, pembentuk identitas nasional dan sistem politik demokratis, serta pilar tatanan masyarakat Madani yang kuat. Sedangkan konsideran yang terakhir menegaskan Islam Nusantara sebagai modal sosialpolitik yang sangat berharga bagi eksistensi bangsa Indonesia, baik dalam kaitannya dengan persoalan dalam negeri maupun dalam pergaulan yang lebih luas di tingkat regional dan global.43

Pesantren sebagai representasi wajah Islam di Indonesia sangat apresiatif dengan agenda besar ini. Sebagai tanggungjawab keagamaan dan komitmen kebangsaan (nasionalisme), pesantren tampil sebagai garda depan untuk menyelamatkan negara dan bangsa dari ancaman dan aksi-aksi gerakan radikal. Membiarkan terhadap ideologi dan radikalisme yang mengatasnamakan Islam secara niscaya akan meruntuhkan bangunan negara dan bangsa juga NKRI. Sikap dan tindakan pesantren yang turut aktif mengawal Islam Nusantara inilah sebagai pencerah bagi masyarakat.

\section{Penutup}

Radikalisasi agama menjadi problema dan hambatan bagi suasana dan perkembangan pesantren. Sebagai konsekuensi, pesantren harus memberikan respon yang signifikan. Menekankan ilmu dasar keimanan kepada santri, menghantarkan pada pemahaman konsep akhlakul karimah yang terejawantahkan pada perilaku santri yang santun dan bermartabat.

Di samping itu, sebagai kekuatan masyarakat pesantren harus menghabituskan wajah multukultural dalam wujud interaksi sosial. Pendidikan pesantren harus berbasis multukultural, artinya pendidikan yang diberikan kepada santri tidak menciptakan pemahaman yang tunggal (monokultural), termasuk di dalamnya pemahaman tentang realitas keberagamaan. Menghormati pluralisme melahirkan humanisme yang akan

43 Konferensi Internasional Islam Nusantara..., diakses tanggal 4 April 2017 membawa makna besar dalam kehidupan bersama dalam segala bidang. Toleransi dalam kehidupan beragama menjadi sangat mutlak adanya, dengan eksisnya berbagai aliran keagamaan dewasa ini.

Islam Nusantara dengan beberapa butir yang dilahirkan dari konferensi besar merupakan salah satu jawaban atas terjadinya keekstreman agama di Indonesia termasuk pesantren di dalamnya. Hal ini menunjukkan bahwa Indonesia termasuk negara yang galak dan berhasil membendung laju ekstrimisme agama. Keberhasilan ini tidak hanya mengangkat nama Indonesia sebagai negara dengan penduduk terbesar di dunia dengan variasi agama di dalamnya sebagai negara damai. Namun, sekaligus membantah persepsi dunia tentang agama Islam yang selalu diidentikkan dengan agama teror dan kebencian.

\section{Pustaka Acuan}

Abrasyi, Muhammad 'Athiyah, al-, Dasar-dasar Pokok Pendidikan Islam, terj. Bustami A. Gani dan Djohar Bahry. Jakarta: Bulan Bintang, 1993.

Alam, Masnur, Model Pesantren Modern Sebagai Alternatif Pendidikan Masa Kini dan Mendatang. Jakarta: GP Press, 2011.

Attas, Syed Muhammad Naquib, al-, (ed), Aims and Objectives of Islamic Education. Jeddah: King Abdul Aziz University,1979.

Azra, Azyumardi, Pergolakan Politik Islam dari Fundamentalisme, Modernisme hingga PostModernisme, Jakarta: Paramadina, 1996. , Waspadai Paham Radikal. Kompas, 7 April 2015.

Bruinessen, Martin Van, Netherlands Paper presented at the ISIM workshop on The Madrasa in Asia. http://murtaufuq.blogspot. com/2008_09_01_archive.html, diakses tanggal 26 Maret 2016.

Dhofier, Zamakhsari, Tradisi Pesantren, Jakarta: LP3ES, 1994.

Faizin, Hamam, "Pesantren Wajah Multikultural Islam Indonesia" dalam Pesantren dan Demokrasi, Jejak Demokrasi Dalam Islam, Jakarta: Titian Pena, 2010.

Hamim, Thoha, "Pesantren Sebagai Alternatif Ideal Bagi Sikap Hidup di Tengah Modernitas" dalam Tadzkirah Jurnal Pendidikan Islam, Vol. 6 Th. 6, Februari 2011. Jombang: UNIPDU, 2011. 
Hedari, Amin et. Al, Masa Depan Pesantren: Dalam Tantangan Modernitas dan Kompleksitas Global, Jakarta: IRD Press, 2004.

BNPT Incar 19 Pondok Pesantren Terindikasi Radikal. http://nasional.komps.com, diakses tanggal 27 Maret 2016.

Imarah, Muhammad, Fundamentalisme Dalam Perspektif Barat dan Islam, terj. Abdul Hayyie al-Kattani, Jakarta: Gema Insani Press, 1999. Indra, Hasbi, Pesantren dan Transformasi Sosial Studi Atas Pemikiran K.H. Abdullah Syafi'ie dalam Bidang Pendidikan Islam, Jakarta: Penamadani, 2003.

Jamhari, Jajang Jahroni, Gerakan Salafi Radikal di Indonesi, Jakarta: Rajawali Press, 2004.

Jamil, Muhsin, Membongkar Mitos Menegakkan Nalar: Pergulatan Islam Liberal versus Islam Literal, Yogayakarta: Pustaka Pelajar, 2005.

Kurzman, Charles, Wacana Islam Liberal: Pemikiran Islam Kontemporer tentang Isu-isu Global, Jakarta: Paramadina, 2001.

Ma'arif, Syamsul, Pesantren vs Kapitalisme Sekolah, Semarang: NEED'S Press, 2008.

Mahendra, Yusril Ihza, Modernisme dan Fundamentalisme dalam Politik Islam, terj. Mun'im A Sirry, Jakarta: Paramadina, 1999.

Mahfud, al-, Anak, Pendidikan Agama, dan Akar Radikalisme. http://harian.analisadaily.com/, diakses tanggal 4 April 2017.

Mardianto, Pisdoni, Sejarah Masuk dan Berkembangnya Islam di Nusantara, http:// pisdonimardianto.blogspot.com/2015, diakses tanggal 28 Maret 2017.

Mastuhu, Dinamika Sistem Pendidikan Pesantren Suatu Kajian Tentang Unsur dan Nilai Sistem Pendidikan Pesantren. Jakarta: INIS, 1994.

Mas'ud, Abdurrahman, Dari Haramain ke Nusantara, Jakarta: Kencana Prenada Media Group, 2006.

Mirri, Seyyed Mohsen, Muthahhari, Antara Literalisme dan Liberalisme, http://selak. blogspot.co.id/2010/02/muthahhari-antaraliteralisme-dan.html?m=1, diakses tanggal 26 Maret 2017.

Mohammad, Yamin, "Standarisasi Pesantren Membendung Radikalisme" dalam https:// beritagar.id/artikel/berita/standarisasipesantren-membendung-radikalisme, diakses tanggal 7 April 2017.
Mutawalli, JIL Menggugat Digugat, Mataram: LKIM IAIN Mataram, 2009.

Nurhayati, Anin, Kurikulum Inovasi Telaah Terhadap Pengembangan Kurikulum Pendidikan Pesantren, Tulungagung: Teras, 2010.

Pinardi, Sigit, "Peneliti: Indikasi Pesantren Radikal Bisa Dilihat Pemimpin dan Alumninya" dalam http://m.antaranews.com/berita/544424, diakses tanggal 4 April 2017.

Qomar, Mudjammil, Pesantren Dari Transformasi Metodologi Menuju Demokratisasi Institusi, Jakarta: Penerbit Erlangga, 2005.

Rahman, Fazlur, Islam dan Modernitas Tentang Transformasi Intelektual, Bandung: Pustaka, 2005.

Rahmat, Imdadun, Arus Baru Islam Radikal, Jakarta: Erlangga, 2005.

Rais, Amin, Cakrawala Islam. Bandung: Mizan, 1999. Shihab, Habib Rizieq, Dialog Piagam Jakarta: Kumpulan Jawaban, Jakarta: Pustaka Ibnu Sidah, 2000.

Roibin, Relasi Agama dan Budaya Masyarakat Kontemporer, Malang: UIN Malang Press, 2009.

Rubaidi, "Negara Dan Radikalisme Agama di Indonesia" dalam Dialektika Teks Suci Agama, ed., Irwan Abdullah, dkk, Yogyakarta: Pustaka Pelajar, 2008.

Suara Hidayatullah, edisi 09.XII/Syawal 1422.

Tibi, Bassam, Ancaman Fundamentalisme: Rajutan Islam Politik Dan Kekacauan Dunia Baru, Yogyakarta: Tiara Wacana, 2000.

Turmudi, Endah dan Riza Sihbudi, Islam dan Radikalisme di Indonesia, Jakarta: LIPI Press, 2005.

Wahid, Abdurrahman, the Wall Street Journal, 30/12/2005.

Wahid, Abdurrahman, Pergulatan Negara, Agama dan Kebudayaan, Jakarta: Desantara, 2001.

Konferensi Internasional Islam Nusantara Hasilkan Piagam Den Haag, www.kemenag.co.id/ berita/480851/konferensi, diakses tanggal 4 April 2017.

Zada, Khamami, Islam Radikal: Pergulatan Ormasormas Islam Garis Keras di Indonesia, Jakarta: Teraju, 2002. 